\title{
REPRESENTATION AND IDENTITY ISSUE BETWEEN GLOBALISM AND LOCALISM: THE CASE OF HONG KONG PAVILION AT THE VENICE BIENNALE
}

Eva Kit Wah Man

Hong Hong Baptist University

\section{A B S T R A C T}

In this presentation Lee Kit's art installation at the Venice Biennale in 2013 is used as a case study of the ways in which artworks represent and help to construct representations of Hong Kong's challenge to and subversion of an aggressive and powerful rising China. In contrast with the explicit social critique and grandeur of artworks exhibited in the China Pavilion, Lee Kit's art installation - "an impressionistic house" - in the Hong Kong Pavilion appears not only abstract but mundane and even trivial. As the artist was handpicked by the organizer, without any prior public consultation, there has been heated public debate on the extent to which it is representative of Hongkongness. I argue that the apparently trivial and ordinary elements of Lee's work constitute rather than reflect the new generation of Hong Kong art. These elements may also be part of a strategy for negotiating the political identity inescapably imposed on Hong Kong by China. Hong Kong art now has the potential to distance itself from or express skepticism toward the grand narratives presented by China, to paraphrase the writing of art historian David Clarke (1997). I believe part of the aims of the international conference on "Hong Kong as Method" held at the University of Hong Kong in December 2014 is to use the ordinary to destabilize and challenge Hong Kong's taken-forgranted political identity and thereby promote diversity and inter-Asian cultural dynamics.

KEY WORDS

INSTALLATION ART

HONG-KONGNESS

CHINESENESS

IDENTITY POLITICS

GOBALISM 
HONG KONG'S PARTICIPATION IN THE VENICE BIENNALE:

\section{A BRIEF HISTORY}

Hong Kong (HK) has participated in the Venice Biennale (VB) seven times since 2001. Its objectives are repeatedly stated as follows: to establish HK's image as an artistic and culturally engaged city; to promote creativity and develop international awareness among local artists through cultural exchange; and to create an environment conducive to the long-term development of the visual arts in HK. Patrick Ho, Chairperson of the Hong Kong Arts Development Council (HKADC) from 1999 to 2005, also suggested that Hong Kong first entered the exhibition to compete with neighboring cities such as Taiwan, which has participated in the VB consistently since 1995, and Singapore, which has taken part irregularly over the years. According to Ho, if HK had missed the opportunity to exhibit at the VB, it would have been "left lagging behind for another 2.5 years, with adverse consequences for our international image." Competition among Asian regions is certainly a powerful motivation to participate, as the VB is regarded as the world's largest international cultural exchange event.

The aims and objectives of HK's participation in the VB were well articulated by the curator of its first exhibition, Johnson Chang. Chang explained that the exhibition had to suit the intellectual climate of the art field, with representatives who were at that time based mainly in Europe and America. It had to convey the essence of HK's creativity, which would surprise viewers accustomed to mainland Chinese and Taiwanese contemporary art. According to Chang, HK artists are much more individualistic than their mainland Chinese and Taiwanese counterparts, and place a greater emphasis on personal experience in their approach to art. The challenge facing Chang was to turn this experience into an artistic statement. ${ }^{2}$ From 2003 to 2011, the HKADC openly invited groups and individuals in the art world to submit proposals for exhibitions; however, the rules changed when the council began to collaborate with $\mathrm{M}+$ (a museum of visual culture due to open in the West Kowloon Cultural District) in 2013.

In 2001, the year of the $49^{\text {th }} \mathrm{VB}$, the HKADC and the Leisure and Cultural Services Department formed a work group to nominate 35 curators, of whom 16 were invited to submit exhibition proposals. Next, an assessment panel was set up to select one individual or team to curate the HK Pavilion at the VB.

In 2003 and 2005, the HKADC issued an open invitation for exhibition proposals for the 50th and $51^{\text {st }}$ VBs. Assessment panels were again set up to select curators/curatorial teams to participate in the VBs in collaboration with the HKADC. 
A similar process was used to select curators/curatorial teams for the $52^{\text {nd }} \mathrm{VB}$ in 2007, the 53rd VB in 2009 and the 54th VB in 2011. However, each of the final announcements met with widespread protest. Most of the objections concerned the selection process, and some turned into legal disputes.

\section{COLLABORATION BETWEEN M+ AND THE HKADC}

On June 22, 2012, the HKADC announced that it would collaborate with $\mathrm{M}+$ in preparation for the VB 2013. As the curators employed by the M+ had considerable experience in running international exhibitions, and numerous networking connections at the VB, the HKADC expected this arrangement to prevent complaints about the selection process. However, the council again received criticism from the visual-arts community, albeit no more severe than previous objections. In a statement made for the media, one representative of the art world observed that "the policy change was made in a black box. Its communication and articulation made the public confused about the roles of the HKADC and $\mathrm{M}+. "$

On July 3, 2012, members of the local art community announced two major concerns in a petition entitled "We Want the Truth." ${ }^{3}$ First, they were troubled that the HKADC was no longer openly seeking proposals from the art community; second, they were concerned by the sum of HK $\$ 10$ million required to fund the project. The members of the art community responsible for the petition held a forum at the HK Fringe Club on October 3, 2012, which was attended by Wilfred Wong, Chairperson of the HKADC, and Lars Nittve, Executive Director of M+. However, "things became sour." During the forum, I observed that the audience's strong negative reaction to the HKADC's collaboration with $\mathrm{M}+$ was due to the insufficient support and attention provided for local visual artists over the years, and their limited opportunity to gain international exposure. They were skeptical about Nittve's understanding of HK art, and expressed concern that his decisions as a curator would adversely affect the development of the region's art. Nittve even announced a plan to present solo exhibitions in the HK Pavilion for five consecutive VBs in the subsequent 10 years. The HKADC and $\mathrm{M}+$ made this decision without public consultation.

Finally, the HKADC and M+ chose Lee Kit to represent HK at the $55^{\text {th }}$ VB in 2013, with an installation named "You (you)." The HKADC and M+ each contributed HK\$ 5 million to fund the project. In late June 2014, the HKADC released a document entitled "Summary of the Evaluation Report on the Venice Art Biennale 2013," confirming its plan for curating the HK Pavilion at the VB in 2015. In this document, the HKADC stated that in collaborating with $\mathrm{M}+$, it aimed "to provide the best environment for our artists to showcase 
their creativity and talent and to achieve the best marketing outcomes for HK's exhibition in Venice." ${ }^{4}$ The increased funding was intended to improve the quality of the HK Pavilion. For example, lavish efforts were made to renovate Hong Kong's small rented building at the entrance to the Arsenale, partly to help it compete with the huge pavilion space in the same area granted to the People's Republic of China in 2011.

The HKADC stated in the report that in its "past experience of organizing exhibitions, curating quality had varied considerably due to the limited number of experienced and capable local curators. Due to a shortage of manpower and administrative problems, it was difficult for both independent curators and curatorial teams to cope with the sheer amount of preparation work, such as the formation of curatorial strategies, financial management, administration, publicity and marketing. The curators involved in each Biennale were unable to pass their experience and insights on to their successors, resulting in discontinuity."

In all of its press releases and reports, the HKADC praised $\mathrm{M}+$ for its professionalism and internationalism, in contrast with local curators, who were described as inexperienced and incapable of handling the work required to prepare a successful exhibition. However, members of the local art community did not believe that the collaboration of the two bodies would truly help local art development. They felt that the rhetoric of professionalism and internationalism was part of M+'s strategy to monopolize the market and squeeze out local artists. ${ }^{6}$

\section{SELECTION OF LEE KIT BY M+}

$\mathrm{M}+$ developed the following criteria for the selection of an artist to represent $\mathrm{HK}$ at the VB:

1. The artist must be a Hong Kong resident.

2. The artist must have experience of producing large-scale visual arts exhibitions.

3. The artist must be capable of producing an art exhibition with an international outlook.

4. The artist's artistic achievements must be both locally and internationally recognized.

Nittve made the following remarks after naming Lee Kit as HK's representative in a press conference. "Lee Kit is to me one of the leading artists in HK's thriving contemporary art scene. I have during my years here been repeatedly touched by how Lee Kit so seemingly effortlessly manages to mix a deep 
understanding of contemporary art with something very personal and intimate. His work is at the same time uncompromising and extraordinarily open for participation, intimate and at the same time public. It truly embodies the fundamental and wonderful uncertainty at the heart of all good art - while bringing together Western and ancient Asian cultural traditions. I am totally confident that Lee Kit has the capacity to make the best out of the perfectly located but far from easy exhibition venue that HK has in Venice!"?

Who is Lee Kit? Lee Kit was born in HK in 1978. While studying at The Chinese University of Hong Kong in the early 2000s, he was selected to hold a solo exhibition in Fo Tan, entitled "Painting Furniture." Although he creates art in numerous media - from painting, video and sculpture to installations and performance - his works are highly recognizable, with a characteristic color palette of subtle pastels and a shared concern with aspects of daily life. The following examples are representative of Lee Kit's recent style and choice of materials: "Something in my Hand" (2010-2012, Layers of used towel, lacquer); "How to Set Up a Room for Johnny" (Jan. 14 - Feb. 12, 2012, Location: Osage Kwun Tong); "Henry (Have You Ever Been This Low?)" (Nov. 18, 2011 - Jan. 14, 2012, Western Front Society, Vancouver).

One month before the HKADC announced its collaboration with M+, Lee won the Art Futures Award at the 2012 Hong Kong International Art Fair.

Lee Kit has participated in group exhibitions in leading museums across the world, such as the "No Soul for Sale" exhibition at the Tate Modern. Lee was represented in the Lombard Freid Projects in New York, and participated in the New Museum Triennial and the Liverpool Biennial in 2012. His contributions to recent exhibitions at museums such as the Museum of Modern Art, the Tate Modern and the Hong Kong Museum of Art seem to confirm Nittve's perceptions of the international expectations of HK art. At the 55th VB in June 2013, The solo he held in the HK Pavilion, was in a small building located at the water entrance to the Arsenale, which is rented by HKADC for the duration of the VB. The exhibition received international critical acclaim, and Lee Kit was selected as one of the "five artists to watch" at the VB.

Some of the responses made by international critics to Lee's exhibition in the HK Pavilion, along with an official assessment of HK's contribution, are provided below:

1. '“You (you)' reflects the expansion of the artist's ambition. Outside the pavilion, Mr. Lee has set up a pair of standard guard booths, ubiquitous in Hong Kong; inside, he has built a domestic mise- en- scene through 
which people can walk, guided by certain clues. However, the stories behind these new works are as lonely as ever. One untitled pair of works includes a painting bearing the scrawled words, 'He stepped on his fingernail.' Underneath the canvas, a row of speakers broadcast the first measures of various ballads. Mr. Lee said that the aim of this combination is to conjure the gut-twisting pain felt when certain songs about lost love are played; the act of listening only wounds the listener, like the act of treading on one's own toes." 8

2. 'In the exhibition entitled 'You (you),' Lee Kit is once again exploring the ambiguous territory between private and public spaces, and the power of installations to evoke emotions connected to real and imagined memories. The exhibition conveys the essence of Lee Kit's art.""

3. "Lee Kit has gone to the opposite extreme in an exhibition so restrained and denuded that visitors can be forgiven for thinking, at least initially, that there is nothing there - just a shirt on a hanger, a plastic glass on a shelf, a faint painting inadvertently left on a wall, a table, some flickering video monitors, someone vacuuming up dust. (Image) Lee, who now divides his time between HK and Taiwan, speaks of his work as evoking memories, ephemeral feelings, questions about identity and subtle domestic dramas. This interpretation is echoed in press materials released by the pavilion's big-gun organizers at HK's forthcoming Museum for Visual Culture: Lars Nittve, the museum's Executive Director, and Yung Ma, its Assistant Curator. However humble Lee's objects and materials, there is no denying the intellectual appeal of his aesthetic." 10

4. "Visiting [Lee Kit's] exhibition was one of my greatest surprises and most enjoyable experiences at the Bienniale. Everything was perfect: from the kindness of the people who received us to the press-release dossier. My encounters with the space, the installation and Lee Kit's work were very moving. The simplicity of the installation contained all of the artist's aesthetic concerns. The tensions between light and color, structure and form, rhythm and harmony were constructed by a complex grammar full of signs and symbols that the spectator has to decipher."

5. "Lee Kit's work offers an experience in which art is not taught, but transmitted; in which the path to follow is not determined by the ideas that might stage successive works, but by their glints, echoes, shadows and reflections, which reduce the distance between art and life. His installations direct our attention to the things we find in life, subjected to tiny variations, which circulate between the sensorial and the intuitive, between the association of ideas and the games of words, and between essences, subtleties, the intuitive and the inexplicable." 11 
According to the assessors' report, the success of the exhibition was chiefly due to the increased budget created by the combined resources of the HKADC and $\mathrm{M}+$, and the decision made by the curatorial team to sensitively transform the space through renovation. The assessor noted that this investment will benefit all future exhibitions in this space. In addition, the assessor praised the selection of the artist, the curatorial team's lightness of touch with regard to the artist's practice, and the decision to avoid any agenda of "national representation." Lars Nittve's involvement in the project was also commended, and Nittve was described as a leading museum professional in the field of contemporary art. The report also suggested that the exhibition may have benefited from the worldwide interest in $\mathrm{M}+$ and the West Kowloon Cultural District project. ${ }^{12}$

The critics' responses and the assessment report were cited in the HKADC's reply to the local art community. The HKADC stated that its decision to collaborate with $\mathrm{M}+$ in preparation for future VBs was based on these positive appraisals.

$\mathrm{M}+$ clearly intended to make HK's participation in the VB eye-catching and extravagant. Two hundred prominent individuals from the art world attended the exhibition's dinner reception, for which a fish market in Venice was transformed into a surreal and artistically designed setting colored throughout in Lee Kit's trademark blue. With such careful preparation, the event could not fail to recreate and rejuvenate public perceptions of HK art. One might ask whether Lee Kit and his work have been able to withstand this intensive process of remaking.

\section{KEY CONCEPTS IN LEE KIT'S WORKS}

The $\mathrm{M}+$ team allowed Lee Kit free rein in creating the exhibition for the VB. His strategy was not simply to provide a retrospective of art already well known in the HK art community, but to produce new works. He was clearly aware of the distinctiveness of HK's artistic identity, but preferred not to emphasize it. He believed that even without such an emphasis, his works would reflect his perceptions of HK's situation and his own perspective as a HK citizen. He appeared very relaxed, but shied away from public participation: "I don't want too much pressure. I just want to do what I like." Yung Ma, the assistant curator who worked with Nittve, indicated that although the everyday objects in Lee Kit's works reflect personal memories and experience, they also evoke collective memories and shared experiences. ${ }^{13}$ The curatorial statement made by the $\mathrm{M}+$ team is provided below:

In the exhibition 'You (you)' at the 55th VB, Lee Kit continued his exploration of the quotidian realm of everyday life by recollecting personal and collective moments associated with emotions from the not- 
so-distant past. He also formulated a series of spatial reconfigurations that coordinate and alternate between 'concealment' and 'revelation'. These reconfigurations departed from the title of the exhibition, which alludes to something universal yet non-existent, to reflect on the construction of places, memories and time through the notion of absence. The exhibition juxtaposed artworks in diverse media, such as moving images, performance, ready-made objects, found images and lighting. Although none of these artworks were representational or pictorial, they were all deeply related to Lee Kit's personal surroundings and experiences. His method of painting is personal and emotive, documenting the passage of time with networks of repeated lines and squares on fabric. These hand-painted pieces of fabric, documents of private experience, were used in the exhibition as ordinary functional items, such as tablecloths, curtains and picnic blankets. They may once have been part of Lee Kit's daily life, but have now been made public in this exhibition. ${ }^{14}$

Lee Kit's 'sparse yet intimate' installations are part of his ongoing attempt to form and suggest traces of immaterial dialogues and relationships. $\mathrm{He}$ meticulously arranges various elements within these installations to reveal the process of painterly composition. His use of repeating patterns, mundane objects and other ephemeral materials in the VB exhibition represents his artistic approach in progress. Critics regarded these materials function as triggers for emotions and sensations, evoking the texture of viewers' memories, both real and imagined.

In ArtReview's questionnaire, Lee Kit responded as follows: "The exhibition is about 'how absence is reflected in the construction of places, memories and time.' $[. .$.$] Creating an exhibition that I am happy with is more important than$ representing Hong Kong." "15

Some additional responses made by critics outside HKADC's invited assessement should be noted.

1. "Lee Kit's [exhibition], located outside the main entrance of the Arsenale, creates a sense of dislocation and othering, and it is consistently sparse. It is compelling, charged with paradoxical sensations of intimacy and alienation, boredom and tenderness. [...] Lee's strength is his unobtrusive ability to simply set a tone, create a mood, trigger a memory or convey a sensation. [...] We are left to fill in the gaps with our own personal recollections. Indeed, the exhibition isn't all about Lee, it's all about '(you)'."'16 
2. "Mr. Lee began his career as a painter. Household fabrics - sheets, towels, tablecloths and curtains - provide a canvas for his abstract works. After painting these fabrics, he often incorporates them into his daily life, using them for their original functions and making them part of a continuous performance." 17

3. "Traversing private domestic settings and public exhibition spaces, Lee's hand-painted fabrics are part of a wide range of signifying practices. However, Lee continues to emphasize the minimalism of his works, insisting that they have no extrinsic meaning. [...] [They] serve more as passive observers witnessing ordinary moments in the artist's life."18

4. "As a result of the artist and curators' reconfiguration of the physical site [of the VB exhibition], this [later] exhibition juxtaposes new commissions with installations from the exhibition in the Biennale, such as daily objects, moving images, sound, found images and paintings, which cross personal, social and political boundaries. [...] One significant aspect of this exhibition is its mood of melancholy and anger. [...] And the M+ assistant curator Yung Ma said that 'the emotions were more transitional [in Venice] and this time they are more extreme.' [...] The feeling of anger is a response to recent social events." ${ }^{\prime 19}$

5. Another commentator (Tsui 2014) emphasized the minimalism of Lee Kit's exhibition and compared it with the art tradition heralded by Duchamp (especially Fountain, 1917). The exhibition was also compared with Eastern minimalist movements in art, such as HK's New Ink Painting Movement. Martin Creed described an "ascetic positivity" in Lee Kit's works. However, the critic also commented that the clear-cut visual imagery and metaphysical inclinations of Lee Kit's installation may "lead to serious withdrawal consequences from audiences due to a lack of connectivity." The writer ended his essay by expressing the hope that Lee Kit will "tell us more of himself through his works." ${ }^{20}$

Lee Kit explained his work as follows. "I minimized the message to the point that I only needed to place the object. [...] [The message] then became my attitude." He described the art scene in HK as a place of retreat from the highly political and competitive atmosphere of the neighboring mainland China. Despite acknowledging that $\mathrm{HK}$ is an inescapable premise of his work, Lee maintains a distance from the heated debate on the city's identity: "without HK, I would not have done this kind of work, but I don't really like to focus on the HK context." Within a culture consumed by cycles of productivity and efficiency, Lee finds solitude as well as creative freedom in the liminal spaces of the city. ${ }^{21}$ 


\section{THE MAKING OF HONG KONG ART}

What are the implications of participating in international art events such as the VB? Whereas contemporary art is often regarded as abstruse, when national boundaries and cultural identities remain very real for most people. Artistic creativity that reflects regional identity offers insights into the complex issue of globalization and its effects on various disciplines. What role should an artist such as Lee Kit, who has been selected to represent HK in the VB, play in the international arena?

HK's artistic identity is a work of cultural production in progress. David Clarke offers a detailed account of the contribution of local artists to the cultural hybridity of HK, with particular attention to the complex ways in which HK artists relate to the cultural narratives of Western modernism and Chinese traditionalism.22 Artists such as Lui Shou-kwan (who pioneered the New Ink Movement in the 1970s) and Van Lau take Chinese culture as their primary framework. However, their projects of modernization are less clear. According to David Clarke, such artists are unwilling to criticize pre-existing images of Chinese culture; instead, they merely juxtapose signifiers of modernity and the West with signifiers of "Chineseness." Wucius Wong, who belongs to the socalled "middle" generation of HK artists, consciously accentuates rather than blurs distinctions between East and West in his paintings. His strategy is to counterbalance Chinese references with signs of modernity.

In contrast, Luis Chan's later paintings and the sculptures produced by Antonio Mak in the 1980s diverge from this binary representation of China and the West, creating space for the artistic expression of "Hong Kongness." Compared with the missionary spirit of Lui Shou-kwan's efforts to fuse Chineseness with Western modernist art, Chan's approach is considerably more playful and tolerant of heterogeneity. He adapts Western modernism with great originality, ease and candor. He draws on both Chinese art and abstract expressionism, and thoroughly integrates Chinese text into Western media, expressing his own style freely. Mak's references to both Western and Chinese culture offer an ironic and distanced perspective on HK. He also elaborates on the theme of opposition, providing powerful political insights and critical parody. Clarke argues that Wong's hybrid style emerged from modernism's first interaction with HK visual culture, whereas Chan's paintings and Mak's sculptures belong to the period of transition from modernism to postmodernism. Clarke thus conceives of this era as a series of "moments of broader cultural change." ${ }^{23}$

Critics have also noted that the 1984 Sino-British Joint Declaration on the Future of Hong Kong and the 1989 Tienanmen incident strengthened the urge to represent HK's cultural identity in art, in parallel with more vociferous calls 
for democracy in local political contexts. In Clarke's words, "Hong Kongness has its distance from or scepticism about grand narratives - it is a species of rootless, non-essentializing, or postmodern identity which might be usefully considered by those concerned with cultural identity politics. ${ }^{24}$ Scholars have argued that certain kinds of hybrid art are likely to be officially endorsed and promoted against a political backdrop of "one country, two systems." Clarke mentions at least two historically distinct varieties of hybrid art. He predicts that a similar semiotic struggle will follow in local art. However, Lee Kit's work is free of any tendency to represent China and the West in binary form. Does his work perfectly fit the description of HK art by M+? Why should his art be promoted an exemplary form of visual culture of HK?

\section{LEE KIT'S WORK AND HK ART}

Recently, critics have made additional observations on the development of HK art, especially artists' responses to HK's return to China. Some examples are provided below. ${ }^{25}$

1. HK art constitutes a fractured field of competing cultural paradigms, which reflect oblique strategies for invoking a sense of local autonomy in cultural terms.

2. Due to the lack of a national framework for discourse about HK identity, techniques such as fabrication, appropriation and mimicry have been foregrounded, accompanied by a superficial retreat to the private and an emphasis on the personal and the somatic.

3. Due to the lack of a "high art" tradition in HK, HK art has a local language, and is part of popular and material culture.

Critics regard these strategies as effective ways of fashioning a competitive social identity in a world of externally created and imposed social facts and meanings.

What insights, if any, do these observations offer into Lee Kit's art and artistic strategies? Before attempting to answer this question, it is crucial to note that Lee's preferred medium, installation art, is also the art form most frequently used by visual artists in HK. The popularity of this medium among HK artists has several implications, as follows. ${ }^{26}$

1. Local artists fashion their own languages by recombining, rearranging, exchanging and incorporating materials from everyday life to articulate new interpretations of personal, cultural and historical events.

2. Installation art offers a means of negotiating with the establishment through the artistic construction of situations and conceptual frameworks. 
3. Installation art is a dynamic and interactive art form that allows an audience to physically participate in the artistic setting and help to formulate the meanings of the works.

4. Finally, we may infer that an alternative HK "reality" has been constructed by the creators of these installations, whose use of local sentiments and local materials prevents their work from merely imitating Western art.

It is generally assumed that the response of most local artists to the everyday experience of post-colonial $\mathrm{HK}$ is individualistic, and expressed in multiple art forms. The creative strategy of HK artists is to formulate their own artistic propositions in response to external changes. Their artistic endeavors are organized around personal experiences and exploration, although not to the exclusion of social and political themes. ${ }^{27}$ The preferred subjects of HK artists are the search for personal identity by tracing personal history, experiments with the integration of technology and expressive media, the relationship between private (experience) and public (exhibitions), and personal responses to social and political events. They suggest that the lack of both a past and a historical vision helps to make life real and immediate. The scenes depicted seem always to be foregrounded with clarity and lucidity, hiding nothing. Johnson Chang's claim that HK's cultural condition is characterized by a sense of naked transparency may accurately describes Lee Kit's work, although his art, at the same time, also explores disappearance, individualism, personal, private and secret experience, and self-contentment. ${ }^{28}$

Johnson Chang, the curator of HK's first exhibition at the VB, notes that events held at the HK Pavillion"[i]t is a show about Hong Kong, but it is also a show about a strategy for modern urban living, which most people from most metropolises can understand." ${ }^{17}$ What else can such people read in HK art? In parallel with the economic reforms implemented by Deng Xaoping, mainland Chinese art took a new direction in the 1980s. It has been observed that Western interest in recent Chinese art was piqued by the emergence of China as a player in the global political arena. As a result, the art of HK received less attention, despite the modernizing influence of the New Ink movement in the late 1960s, and the rejection of the master narratives of both China and the West by postmodern HK artists. ${ }^{30}$ For instance, in honor of its first exhibition at the VB in 2011, China was given a vast area of unused factory space in which to construct the China Pavilion. China's and HK's pavilions are at opposite ends of the Arsenale exhibition hall, and the former has monopolized viewers' attention, due to China's rapid rise and opening up. The opening of the China Pavilion at the VB had a huge audience, and its first and second exhibitions were curated to display every detail of China's artistic production with grandeur and on a large scale, in proportion with the nation's population. 
Clarke's claim that HK art works to affirm HK identity or subjecthood, and to some extent helped to create it, seems valid. However, one must ask whether HK art truly tends to express local cultural identity obliquely and negatively rather than directly and positively; and if so, why. Explanations were given as follow, agreeable or not, using $\mathrm{HK}$ as method $^{31}$ :

1. HK artists' oblique and negative representations of HK identity disaffirm the incorporation of HK into China's national identity, opening up an alternative space for Hong Kongness.

2. Mainland Chinese artists tend to conceive of Chinese culture as a homogeneous national framework, whereas HK artists are more concerned with the distinctions - both physical and psychological between the ex-colony and China.

3. HK artists prefer to use items from popular and material culture and pre-existing objects as resources in their art.

4. HK artists seek to maintain pre-existing patterns of HK life, and fear that such patterns may be lost or "disappear."

Critics in the fields of art and culture regard the latter phenomenon as a form of nostalgia, and conclude that "much of the best Hong Kong art is concerned with offering an alternative sense of subjecthood that is not framed in national terms. ${ }^{" 32}$ Identity is thus constructed by both the artistic subjects and their interpreters. These tendencies help to explain HK artists' choice of medium, as an emphasis on the local leads quite naturally to engagement with installation art and photography.

Are these the reasons for Lee Kit's selection by a foreign curator? How does Lee Kit's work relate to HK's identity issues and image when he himself has claimed retreat from the subject? Gordon Mathews suggests that two broad constructions of HK cultural identity exist: "Hong Kong as a part of China" and "Hong Kong as apart from China". ${ }^{33}$

According to Mathews, the cultural identity of "Hongkongese" that emerged in the 1960s had three main dimensions: 1) "Chineseness plus affluencel cosmopolitanism/capitalism," 2) "Chineseness plus English/colonial education/colonialism," and 3) "Chineseness plus democracy/human rights/ the rule of law. ${ }^{34}$ One may argue that Lee Kit's generation of artists, especially those born in HK after the 1970s, possesses the newly emergent HK identity of affluent cosmopolitan choice; in other words, they have an autonomous, critical, independent Chinese identity that cannot be controlled. This identity certainly seems to be reflected in Lee Kit's installations. The exhibition entitled "You (you)" in the HK pavilion at the VB, which is free and private, represents 
a strategy for protecting one's personal integrity. Lee's installation is a selfdefense mechanism rather than a means of reaching out. It expresses personal values and an attachment to private, natural experiences, suggesting that the process of making art is always one of intense personal need; it is intentionally obscure and full of closed, self-reflexive references. One might say that Lee's work is basically anti-political; as Johnson Chang suggests, it resembles a private, incommunicable diary. ${ }^{35}$ Indeed, this is the predominant perception and conception of HK art today.

\section{THE HK PAVILION AS A MEANS OF EXPRESSING HK IDENTITY}

Describing Lee Kit's work as a form of disappearance, Carolyn Cartier (2012) suggests that accounts of HK culture tend to portray the city in terms of the vanishing present and the transitional moment. Therefore, disappearance is regarded as more a cultural strategy than a condition of cultural production. International critics stress the political dimensions of $\mathrm{HK}$ art, arguing that contemporary alternative art that addresses disappearance occupies liminal territory and locates its "precariousness" in its lack of definitive status and uncertain future. Accordingly, as Cartier elaborates, "contemporary cultural projects anticipate instabilities of the present, identify hegemonic political economic logics and seek modes of resistance." ${ }^{" 36}$ More recently, international critics have emphasized the multiplicity of representations in HK art of postcolonial life, territoriality, political authority and cultural difference; in short, the dilemma of "Hong Kong in China." As Cartier observes, scholars wonder whether HK artists will be capable of further engaging with and challenging the local and national political economy, enabling their art to transcend "the local." If so, the precariousness of HK art and its logic of cultural production will become entrained within the world's art system.

Does Lee Kit's work produced according to a deliberate strategy or objective? Does it reflect the conditions of cultural production? The emphasis on disappearance in Lee Kit's art connects us to Abbas's (1997) influential work in Hong Kong: Culture and the Politics of Disappearance. Here, Abbas argues for "[an artistic] subjectivity in a space of disappearance," referring to the end of the colonial era, and claims that "postcoloniality is a tactic and a practice" that addresses an imaginary future. ${ }^{37}$ The privacy of Lee Kit's style and attitudes is read as a form of "localness" that deviates from the canonical tradition of "Chinese art" and other essentialist positions. However, an essentializing position is also a manifestation of identity politics, whether created by the artist or interpreted as such by local and international critics. Cartier reminds us of Frank Vigneron's statement that "Hong Kong art" does not exist alone; it must be understood in context. ${ }^{38}$ 
According to Cartier, art that reframes itself outside national contexts represents a politico-aesthetic effort to make inventive and innovative modes of cultural production visible and sensible. ${ }^{39}$ More specifically, HK art integrates art with daily urban life, as exemplified in Lee Kit's work.

Having read Lee Kit's interview with the ArtReview, I concede the point that Lee's works urge us to consider the political significance of all of the facets of daily HK life, and to build an identity for the city from these seemingly quotidian details. In the interview, the artist explained that his exhibition at the VB shows "how absence is reflected in the construction of places, memories and time. ${ }^{" 40}$ However, Lee continues to emphasize the minimalism of his works, insisting that they have no extrinsic meaning, and that they "serve more as passive observers witnessing ordinary moments in the artist's life." ${ }^{\prime 1} \mathrm{He}$ does describe the art scene in $\mathrm{HK}$ as a place of retreat from the highly political and competitive atmosphere of the neighboring mainland China.

This relationship is reflected in the real locations of the HK Pavilion and the China Pavilion at the VB. In the case of Lee Kit, the "HK Method" involves the use of the ordinary to destabilize and challenge the taken-for-granted nature of HK's identity. Lee's work uses the apparently trivial details of ordinary life to construct rather than to reflect the new generation of HK art. This may also be a means of subverting the political identity imposed on HK by China's omnipresent governance. To paraphrase David Clarke, HK art offers the opportunity for HK to distance itself from or express skepticism towards the grand narratives presented by China, and to open up a space for HK identity through irony. ${ }^{42}$

I would like to end the discussion by quoting Richard Vine's observation stated in Art in America regarding Lee Kit's work at the VB:

"What are the consequences of a passive attachment to the mundane in a city like Hong Kong, which is at once a consumerist cauldron and a city under threat of human rights curtailment now that it has been returned to mainland Chinese control? Is there a point at which artistic modesty, pushed too far, becomes its own contrary - a form of overly tasteful ostentation?"43

I argue that the act of simultaneously producing and affirming $\mathrm{HK}$ art is a strategy intrinsic to HK identity, adopted in the HK Pavilion at the VB not only in Lee Kit's art, but in future solo exhibitions curated by M+ to represent HK on the international stage. 
Hilary Blinks, “A Larger Identity,” Asian Art News Vol. 11, No. 5(2001): 72.

Ibid., 73.

Facebook on the protest event, "We Want the Truth", and related materials. https://www. facebook.com/events/413614548705386/, retrieved on November 22, 2014.

"Lee Kit to Represent Hong Kong at the 2013 Venice Biennale", http://www.hkadcorg.hk/en/content/web. do?page-pressrelease20120622, posted in June 2012.

"Summary of the Evaluation Report on the Venice Art Biennale 2013", http://www.hkadc.org.hk/ en/content/web.do?id=4ac14e32468164e30146d79076fa0028, posted on June 28, 2014.

Facebook on the protest event, "We Want the Truth", and related materials. https://www. facebook.com/events/413614548705386/, retrieved on November 22, 2014.

Hilary Blinks, “A Larger Identity,”, 73.

Vivienne Chow, "Artist Lee Kit mulls how to put Hong Kong's best foot forward, " South China Morning Post, April 22, 2013.

JJ Acuna, “Meanwhile in Venice, Lee Kit Makes A Home.” The Wanderlister+(Weblog). Accessed Nov 10, 2014. http://www.wanderlister.com/post/51733581659/meanwhile-in-venicelee-kit-makes-a-home-m\#.VQFByI6Ufg8.

Richard Vine, "China: One Country, Three Pavilions," Art in America, Jun 11, 2013. Accessed Nov 14, 2014. http://www.artinamericamagazine.com/news-features/news/china-one-countrythree-pavilions.

Responses 4 \& 5, see "Summary of Assessors' Reports for The Hong Kong's Exhibition in the 55th Venice Art Biennale 2013"(I \& II), Summary of the Evaluation Report on the Venice Art Biennale 2013 (annex 2). Hong Kong Arts Development Council, posted on June 26, 2014. http://www.hkadc.org.hk/en/content/web.do?id=4ac14e32468164e30146d79076fa0028, retrieved on Oct 26, 2014.

Ibid.

Vivienne Chow, "Artist Lee Kit adds melancholy to exhibition from Venice Biennale.” South China Morning Post, March 6, 2014.

Lars Nittve and Ma, Yung. “'You (you).' - Lee Kit.” Hong Kong: 2013. Accessed Nov 7, 2014. http://www.venicebiennale.hk/2013/exhibition/you-you-lee-kit/.

ArtReview Questionnaire \#20: Lee Kit (London: 2013). Http://artreview.com/previews/20_ venice_lee_kit/, retrieved on Nov. 7, 2014.

Wenny Teo, "Lee Kit's "You (you)" is Great (Great)," The Art Newspaper, June 18, 2013.

Doretta Lau, “A Political Bent, Except in His Art, in Scene Asia," The Wall Street Journal, June $19,2012$.

Stephanie Hsu, “A Report on Lee Kit.” Asian Art Archive documents. Accessed Nov 10, 2014 http://www.aaa-a.org/programs/a-report-on-lee-kit/.

Vivienne Chow, “Artist Lee Kit adds melancholy to exhibition from Venice Biennale." South China Morning Post, March 6, 2014.

H. C. Tsui, "You/me, Martin Creed and Lee Kit," In Arts Wise (H. C. Tsui's blog). Accessed Nov 7, 2014. http://artswise.blogspot.hk/2014/05/youme-and-lee-kit.html.

Vivienne Chow, “Artist Lee Kit mulls how to put Hong Kong's best foot forward," South China Morning Post, April 22, 2013.

David Clarke, "Varieties of Cultural Hybridity: Hong Kong Art in the Late Colonial Era," Public Culture 9(1997): 395-415.

Ibid., 396.

Ibid., 414.

Ibid.

King-Chung Siu, "Theoretical Explorations of Installation Art," Complement and Supplement: Appreciation of Hong Kong Installation Art, ed. WilliaPun Ngai and Yee Lai-manm Cheung, 148-172. Hong Kong: Step Forward, 1999. 
Oscar Ho, In the point of searching, Chinese faces. New Voices from the Two Coasts, Contemporary Painting Languages (Taipei: Museum of National Taiwan Art Education, 1998). Johnson Chang, The Secret Artist: Is Hong Kong Art the True Underground? Private Content: Public View (Hong Kong: Hong Kong Fringe Festival, 1996).

Hilary Blinks, “A Larger Identity,”, 72.

David Clarke, "The Culture of a Border Within: Hong Kong Art and China," Art Journal Vol. 59, No. 2(2000): 89-90.

Ibid., 91-98.

Ibid., 100.

Gordon Mathews, "Hèunggóngyàhn: On the Past, Present, and Future of Hong Kong Identity." Bulletin of Concerned Asian Scholars 29(3)(1997): 52. Reprinted in Narrating Hong Kong Culture and Identity, edited by Pun Ngai and Yee Lai-man (Hong Kong: Oxford University Press, 2003).

Ibid.,72.

Johnson Chang, The Secret Artist: Is Hong Kong Art the True Underground? Private Content: Public View (Hong Kong: Hong Kong Fringe Festival, 1996), 84-86.

Carolyn Cartier, "Image, Precariousness and the Logic of Cultural Production in Hong Kong." PORTAL Journal of Multidisciplinary International Studies. (2012) Accessed August 2, 2015. https://epress.lib.uts.edu.au/journals/index.php/portal/article/view/2554

Ackbar Abbas, Hong Kong: Culture and the Politics of Disappearance (Hong Kong: Hong Kong University Press, 1997), 10.

Wenny Teo, "Lee Kit's "You (you)" is Great (Great)," The Art Newspaper, June 18, 2013. Ibid.

ArtReview Questionnaire \#20: Lee Kit (London: 2013). http://artreview.com/previews/20 venice_lee_kit/. Retrieved on Nov. 16, 2014.

Stephanie Hsu, “A Report on Lee Kit,” Asian Art Archive documents. Accessed Nov 10, 2014. http://www.aaa-a.org/programs/a-report-on-lee-kit/.

Hilary Blinks, “A Larger Identity,”, 407.

Richard Vine, "China: One Country, Three Pavilions," Art in America, Jun 11, 2013. Accessed Nov 14, 2014. http://www.artinamericamagazine.com/news-features/news/china-one-countrythree-pavilions.

Abbas, Ackbar. Hong Kong: Culture and the Politics of Disappearance. Hong Kong: Hong Kong University Press, 1997.

Acuna, JJ. “Meanwhile in Venice, Lee Kit Makes A Home.” The Wanderlister+(Weblog). Accessed Nov 10, 2014. http://www.wanderlister.com/post/51733581659/meanwhile-in-venice-lee-kitmakes-a-home-m\#.VQFByI6Ufg8.

Blinks, Hilary. “A Larger Identity”. Asian Art News Vol. 11, No. 5(2001): 70-73.

Cartier, Carolyn. "Image, Precariousness and the Logic of Cultural Production in Hong Kong." PORTAL Journal of Multidisciplinary International Studies. (2012) Accessed August 2, 2015. https://epress.lib.uts.edu.au/journals/index.php/portal/article/view/2554

Chang, Johnson. The Secret Artist: Is Hong Kong Art the True Underground? Private Content: Public View. Hong Kong: Hong Kong Fringe Festival, 1996.

Chow, Kelly. "Venice: 5 Artists to Watch." The Wall Street Journal [Asia and International Edition], May 30, 2013.

Chow, Vivienne. “Artist Lee Kit mulls how to put Hong Kong's best foot forward.” South China Morning Post, April 22, 2013.

Chow, Vivienne. "Artist Lee Kit adds melancholy to exhibition from Venice Biennale." South China Morning Post, March 6, 2014. 
Clarke, David. "Varieties of Cultural Hybridity: Hong Kong Art in the Late Colonial Era." Public Culture 9(1997): 395-415.

Clarke, David. "Making Art in the Shadow of the Future: Hong Kong Artists and the 1997 Transfer of Sovereignty." In Hong Kong Art Review, edited by Wear Eric Otto and Ho Hingkay Oscar, 4-21. Hong Kong: AICA, 1999.

Clarke, David. "The Culture of a Border Within: Hong Kong Art and China." Art Journal Vol. 59, No. 2(2000): 88-101.

Hsu, Stephanie. “A Report on Lee Kit.” Asian Art Archive documents. Accessed Nov 10, 2014. http://www.aaa-a.org/programs/a-report-on-lee-kit/.

Ho, Oscar. In the point of searching, Chinese faces. New Voices from the Two Coasts, Contemporary Painting Languages. Taipei: Museum of National Taiwan Art Education, 1998.

Lau, Doretta. "A Political Bent, Except in His Art, in Scene Asia." The Wall Street Journal, June 19, 2012.

Mathews, Gordon. "Hèunggóngyàhn: On the Past, Present, and Future of Hong Kong Identity." Bulletin of Concerned Asian Scholars 29(3)(1997): 3-13. Reprinted in Narrating Hong Kong Culture and Identity, edited by Pun Ngai and Yee Lai-man. Hong Kong: Oxford University Press, 2003.

Nittve, Lars (ed.) "Lee Kit to Represent Hong Kong at the 2013 Venice Biennale." Hong Kong: HKADC website. Accessed Oct 18, 2014. http://www.hkadc.org.hk/en/content/web. do?page= pressrelease20120622.

Nittve, Lars and Ma, Yung. “'You (you).' - Lee Kit.” Hong Kong: 2013. Accessed Nov 7, 2014. http://www.venicebiennale.hk/2013/exhibition/you-you-lee-kit/.

Siu, King-Chung. "Theoretical Explorations of Installation Art." In Complement and Supplement: Appreciation of Hong Kong Installation Art, edited by WilliaPun Ngai and Yee Lai-manm Cheung, 148-172. Hong Kong: Step Forward, 1999.

Teo, Wenny. "Lee Kit's "You (you)" is Great (Great)." The Art Newspaper, June 18, 2013.

Tsui, H. C. (a.k.a. Sundial) "You/me, Martin Creed and Lee Kit.” In Arts Wise (H. C. Tsui's blog). Accessed Nov 7, 2014. http://artswise.blogspot.hk/2014/05/youme-and-lee-kit.html.

Vine, Richard. "China: One Country, Three Pavilions." Art in America, Jun 11, 2013. Accessed Nov 14, 2014. http://www.artinamericamagazine.com/news-features/news/china-one-countrythree-pavilions.

Facebook on the protest event. "We Want the Truth", and related materials. Accessed Nov 22, 2014. https://www.facebook.com/events/413614548705386/.

Questionnaire \#20. 2013. Lee Kit. Art Review. London. Accessed Nov 16, 2014. http://artreview. com/previews/20_venice_lee_kit/.

Summary of Assessors' Reports for The Hong Kong's Exhibition in the 55th Venice Art Biennale 2013. (I \& II) Summary of the Evaluation Report on the Venice Art Biennale 2013 (annex 2). Hong Kong Arts Development Council, posted on June 26, 2014. http://www.hkadc.org.hk/en/ content $/$ web.do?id=4ac14e32468164e30146d79076fa0028. Accessed 28 Oct 2014. 


\section{ETIKA STANOVANJA: RANI HRIŠĆANSKI PRINCIPI GRADSKOG ŽIVOTA I URBANE TRANSFORMACIJE \\ Vladimir Mako}

Rad se fokusira na određeno pitanje u vezi etike koja se razvila u ranom hrišćanskom vremenu i njenog uticaja na proces transformacije rimskog urbanog života, navika, funkcije i arhitektonske prakse krajem petog veka i nakon toga.

Složenost ovog pitanja proizilazi iz činjenice da su rani hrišćanski monaški ideali, koji su se brzo razvili u prvim vekovima nove ere, značajno uticali na formiranje svakodnevnih životnih etičkih principa.

Shodno tome, ovi novi principi su promenili postojeće navike u stanovanju, posebno u oblasti javnog života, zahtevajući novi oblik ponašanja od hrišćanskih građana. Ovaj proces je uticao i na idealistički pogled na ono što koncept hrišćanskog grada može biti, i kako se novi oblik etičkog života odražava na nove urbane i arhitektonske strukture.

KLJUČNE REČI: ETIKA, ESTETIKA, GRADSKI ŽIVOT, URBANA TRANSFORMACIJA

\section{UMETNOST, MODERNOST I SKEPTICIZAM \\ Nikola Dedić}

Ovaj rad se bavi problemom odnosa umetnosti i modernosti - naša osnovna teza je da se umetnik u eri modernosti bavi problemom privatnosti. Pojam privatnosti se koristi u Vitgenštajnovom smislu, kao analogija njegovoj teoretizaciji fantazije privatnog jezika. Njegov koncept privatnog jezika je opis povlačenja običnog jezika iz procesa međudruštvenih odnosa i njegove svakodnevne upotrebe; na taj način, fantazija privatnog jezika je vrsta skepticizma. S obzirom na to da je pojam epistemološkog skepticizma povezan sa idejom modernosti (Dekartov, Hjumov, Lokov moderni skeptični predmet), glavni problem za savremenog umetnika je kako da prevaziđe stanje radikalnog skepticizma, odnosno uslov koji Stenli Kavel u Vitgenštajnovom smislu naziva 'metafizička izolacija'.

KLJUČNE REČI: UMETNOST, MODERNOST, SKEPTICIZAM, PRIVATNI JEZIK, OBIČAN JEZIK, LUDVIG VITGENŠTAJN, STENLI KAVEL

OD TRANSCENDENTALNOG IDEALIZMA DO TRANSCENDENTALNOG

EMPIRIZMA I ŠIRE: KANT, DELEZ I RAVNA ONTOLOGIJA UMETNOSTI Andrija Filipović

U ovom radu ću pokazati da pokret od Kantovog transcendentalnog idealizma do Žil Delezovog transcendentalnog empirizma, a zatim do novih materializma i spekulativnih realizma je ono što nam omogućava da razgovaramo o direktnom i ne-posredovanom pristupu stvari u sebi (ili njenom raspadanju). Drugim rečima, to je promena od uslova mogućeg iskustva do uslova realnog iskustva koja su omogućila trenutne filozofske i teorijske diskurse materializma i realizma. Ono što je od posebnog interesa za potrebe ovog rada je kako je promena od uslova mogućeg do stvarnog iskustva povezana sa trenutnom konceptualizacijom umetničkih praksi. Tačnije, ja ću pokazati kako se ontologija umetnosti promenila, ili barem da se možda čini da postoji mogućnost premeštanja paradigme različitih estetika i ontologija umetnosti, gde je ravna ontologija jedna od njih, sa pojavom novih materializma i spekulativnih realizma koji su omogućeni promenom u uslovima realnog iskustva.

KLJUČNE REČI: TRANSCENDENTALNI IDEALIZAM, TRANSCENDENTALNI EMPIRIZAM, RAVNA ONTOLOGIJA,

UMETNOST, KANT, DELEZ

IMPLIKACIJE VATIMOVOG VERWINDUNG-A MODERNIZMA

\section{U ARHITEKTONSKOJ TEORIJI}

\section{Vladimir Stevanović}

U postmodernom dobu, osim novog pristupa arhitektonskoj praksi, dešavaju se značajne promene u bavljenju arhitektonskim pisanjem i to zahvaljujući uplivu postmoderne transdisciplinarne teorije u arhitektonski diskurs. Arhitektonski teoretičari, kritičari i istoričari rado koriste doprinos 
filozofije, političkih nauka, sociologije, teorije umetnosti i književne kritike na polju kategorizacije i interpretacije postmodernih arhitektonskih stilova ili tendencija. Kako formalno-likovni aspekti prestaju da budu ekskluzivni faktor koji konstituiše stil ili tendenciju, dolazi do implementacije tema i paradigmi iz raznih postmodernih teorija, što dovodi do fenomena prevođenja teorije za arhitektonske potrebe. U većini slučajeva teorijski nazori služe kao pokriće u skladu sa kojim teoretičari arhitekture formulišu autorske poetike određenih arhitekata, proglašavaju poželjne modele recepcije njihovih arhitektonskih dela, i formiraju ukupne stavove prema disciplinarnom i društveno-istorijskom kontekstu. Međutim, postaje interesantno kada ista arhitektonska dela jednog ili više arhitekata bivaju na različite načine interpretirana od strane različitih arhitektonskih teoretičara. U tom smislu, rad sagledava ove premise na konkretnom primeru (1) u kome praksu čini Katalonska arhitektura osamdesetih, (2) u kome se ukrštaju ideje de Solà-Moralesa, Rosija i Fremptona, (3) a teorijski obrazac na koji se može fokusirati je Vatimov filozofski koncept Verwindung-a modernizma.

KLJUČNE REČI: VERWINDUNG, SLABA MISAO, MODERNIZAM, POSTMODERNIZAM, FUNDAMENTALIZAM, FRAGMENTARNOST

PITANJE PREDSTAVLJANJA I IDENTITETA IZMEĐU GLOBALIZMA I LOKALIZMA: SLUČAJ PAVILJONA HONG KONGA NA VENECIJANSKOM BIJENALU

\section{Eva Kit Vah Man}

Ovaj rad uzima umetničku instalaciju Li Kita izloženu u paviljonu Hong Konga na Bijenalu u Veneciji 2013. godine, kao studiju slučaja da ilustruje načine na koje dela nude i pomažu sačinjavanje izazvanog Hong Konga i subverziju agresivne i moćno rastuću Kine. Za razliku od 'očigledne' društvene kritike i 'grandioznog' izgleda umetničkih dela izloženih u kineskom paviljonu, Li Kitova umetnička instalacija - "impresionistička kuća” - u Hong Kongovom paviljonu ne samo da izgleda apstraktno, već i svetovno i čak i trivijalno. Pošto je umetnik bio izabran od strane organizatora bez učešća javnosti, ovo je generisalo žestoku javnu raspravu o reprezentativnosti 'Hongkongnosti' ove instalacije. Moja tvrdnja je da je ono što se čini trivijalnim i običnim u Lijevom radu predstavljeno da konstitutiše, a ne prikaže, umetnost nove generacije Hong Konga. To takođe može biti taktika manevarisanja političkim identitetom koji je nametnula Kina Hong Kongu svojim sveprisutnim i pritiskajućim prisustvom. Umetnost Hong Konga ima potencijal da se udalji ili da sumnja u velike narative Kine, da parafraziram reči istoričara umetnosti Dejvida Klarka (1997). Verujem da je motiv međunarodne konferencije "Hong Kong kao metod" decembra 2014. na Univerzitetu u Hong Kongu bio da upotrebom očekivanog destabilizuje i ospori hongkonški "zdravo-za-gotovo" politički identitet i na taj način promoviše raznolikosti i međuazijsku kulturnu dinamiku.

KLJUČNE REČI: UMETNOST INSTALACIJA, HONGKONGNOST, KINESKOST, POLITIKA IDENTITETA, GLOBALIZAM

SAVREMENA KINESKA UMETNOST:

MAOVO NASLEĐE I DANTOOVA DEFINICIJA

Mary Bittner Wiseman

U ovom radu pokušala sam da izvedem tri stvari. Kao prvo, da identifikujem nekoliko tema $\mathrm{u}$ savremenoj kineskoj umetnosti kroz koje pokazuje svoju suštinski socijalna prirodu i svoj robustan materijalizam, karakteristike kojih nema često u zapadnoj umetnosti. Drugo, da ukažem da način na koji je savremena umetnost u Kini postmoderna jete način na koji je i zapadna umetnost, i da potkrepim tvrdnju da koliko god da su teme i nedavna istorija ove umetnosti drugačije od zapadnog pandana, ova umetnost zadovoljava definiciju umetnosti koju je konstruisao Artur Danto, a to je ona koja na fino zaokružuje i širinu i dubinu koncepta umetnosti. Konačno, u poslednjem delu, predstaviću rad jedne žene-umetnika koji se razlikuje od većine skorašnjih kineskih radova i tipičnih radova zapadne umetnost. On se pozicionira na marginama onoga što je umetnost u Kini i što Dantoova definicija obuhvata, istovremeno sugerišući srž umetničke prakse i jedan od načina biti žena. 